\title{
英国・日本・中国の被験者による河川景観評価構造の比較分析 \\ COMPARATIVE ANALYSIS ON THE EVALUATION STRUCTURE OF RIVER LANDSCAPES BY THE SUBJECTS IN ENGLAND, JAPAN AND CHINA
}

\author{
金 華*，西名大作**，村川三郎***，飯尾昭彦**** \\ Hua JIN, Daisaku NISHINA, Saburo MURAKAWA \\ and Akihiko IIO
}

\begin{abstract}
The social and cultural background of subjects is one of the important factors on evaluation of environment or landscape. To clarify the effect of these differences, the experiment was carried out using the photographs of river landscape. The subjects were university students who lived in England, Japan and China-In first, the psychological evaluation of landscapes such as the average evaluative scores of synthetic and individual evaluation, and the structure and the factor scores of evaluation with Image Measurement were analyzed among the three countries. After comparing the relation between the physical character and psychological evaluation, the similarity was found in individual items such as the amount of greenery and water and so on, and the differences were shown on synthetic items such as the feelings of satisfaction for landscape and water stream, because the social and cultural environment of the three countries is different and it would have an effect on evaluation.
\end{abstract}

\section{Keywords: River Landscape, Physical Characteristics, Psychological Evaluation \\ Evaluation structure, Cross-cultural Comparison 河川景観、物理的特性、心理的評価、評価構造、異文化比較}

\section{1. 序}

人間とそれをとりまく環境や景観は相互に大きな影響を及ぼしあ っている。したがって、快適な居住環境づくりや美しい景観の創造 にあたっては、そこに住む人々の評価構造を明らかにしておくこと が重要である。しかし：その評価においては、評価主体である人々 の個人差による影響は否定できない。この個人差とは、讃井ら 》、 槙ら2などの研究て指摘されたような、街路景観や居住環境評価に おける人々の考元方など個人的な差だけではなく、社会・文化的背 景や、生育環境における自然環境の様相なども含んでいることが予 想される。そこで、異なる出身国を有するという背景が、評価に影 響を及ぼす一つの要因となることが考えられる。

このような出身国の異なる集団間の評価としては、鈴木ら 3.、杉 尾4、岡島ららカなどが、伝統的な建物や庭園景観を対象として検討 するなど、国内で幾つかの研究がみられる。また、国外においても、

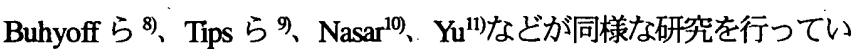
る。このような既往研究をふまえて、筆者らはさらなる展開を図る ベく、留学生や日本人を対象として、生活瑗境やみどり環境 (景観) における評価構造の差異、並びにその要因について、幾つかの研究 12) 14)を進めてきている。しかし、これらの研究では、心理的な評価 構造に着目しているものの、環境や景観の物理的側面と評価との関
連についてはまだ十分な検討に至っていない。

そこで本研究では、評価者の社会・文化的背景の相違が、環境 (景 観を含む）評価に及ぼす影響をより明確に把握することを意図し、 出身国の異なる被験者による、国内外河川景観スライドを用いた評 価実験を実施した。すなわち、本研究では異なる集団間での心理的 評価の相違を把握し、景観構成要素の面積的特徴量を物理的特性と して取り上げ、筆者らが既に提案した景観評価予測式 19を適用する ことによって、心理的評価との関連性を比較検討し、社会・文化的 背景による、景観の認識・評価構造の異同を明確にすることを目的 としている。

なお、既往研究 ${ }^{12}$ 14)において評価対象者として取り上げた留学生 の場合は、サンプル数に対して出身国数が多く、属性も多様であっ たことから、出身国の違いという社会・文化的背景之評価との関連 や、それぞれの評価構造についてより詳細に分析を行うためには、 属性の共通性が高い被験者を出身国ごと、にある程度のサンプル数 を確保することが必要と考えた。そこで本研究では、出身国を限定 して、実験の機会が得られた英国、日本、中国それぞれの大学生を 被験者とした。

また、本研究は、文献10〜17をもとに加筆・再編したものである。

\footnotetext{
* 広島大学大学院工学研究科 修士(工学)

** 広島大学大学院工学研究科 助教授・博士 (工学)

*** 広島大学大学院工学研究科 教授. 工博

**** 日本女子大学家政学部 教授・工博

Graduate Student, Graduate School of Eng., Hiroshima Univ., M. Eng.

Assoc. Prof., Graduate School of Eng., Hiroshima Univ., Dr. Eng.

Prof., Graduate School of Eng., Hiroshima Univ., Dr. Eng.

Prof., Faculty of Home Economics, Japan Woman's Univ., Dr. Eng.
} 


\section{2. 実験概要}

\section{1 実験方法}

実験は、1997 年 12 月〜1998 年 10 月の間に、24 種類の国内外河 川景観のスライド映像を、英国のロンドン大学 (72 名)、日本の広 島大学 (85 名)、中国の大連理工大学 (100 名) それぞれの学生を被 験者として呈示し、各影観に対する心理的評価を求めた。実験には、 各大学の講義室を使用したため、各国で実験状況を完全に統一する ことは困難であったが、被験者から眺めた場合に、視野中に占める スライド映像の大きさが極端に変わらないように被験者の着座位置 に留意した。このようにして、日本と中国の場合、1 回 25〜35 人程 度で 3、4 回、英国では少人数のグループで 20 回以上の実験を行つ た。なお、英国の実験では、英国人のほかに他の欧米諸国出身の学 生も被験者としたが、本研究ではそれらの実験結果を割懓し、英国 人のデータ（65名）のみを対象に分析を行う。

実験手順としては、はじめに実験者が 5〜10 分間の教示を行い、 次に個人属性に関する質問への記入を求めた。その後、各スライド を予め定めたランダムな呈示順序に従って 5 秒間隔で呈示し、評価 対象の全容を把握させた後、改めて最初から同一順序でスライドを 呈示し、順次評価を求めた。スライド 1 枚の呈示時間は被験者全員 の評価が終了するまで概ね 3 分間を要し、実験時間は全体で約 80 分を要した。なお、景観の呈示順序は各回ごとに異なるように配慮 した。

\section{2 回答票の内容}

実験に用いた回答票は被験者の個人特性に関するフェースシート と、呈示した各景観に対する評価に大別される。それぞれ質問項目 の内容を表-1 に示す。フェースシートには、性別、年齢などの被 験者属性と、社会生活において遭遇するさまざまな場面における個 人の価値観に関する項目のほか、評価対象景観が河川という水空間 を中心としたものであり、また、多様な地域からそれらを選択して いることから、河川に対する個人の意識やこれまでの接触程度に関 する項目、さまざまな国や地域に対する関心や経験に関する項目を 加えている。各景観に対する評価としては、個人の嗜好や景観の物 理的環境特性を反映する総体的・個別的評価 7 項目注1) と、SD法 によるイメージ評価 20 形容詞対を選定した。なお、英国、中国での 実験にあたっては、日本語で作成した回答票をそれぞれ英訳・中訳 して用いた。
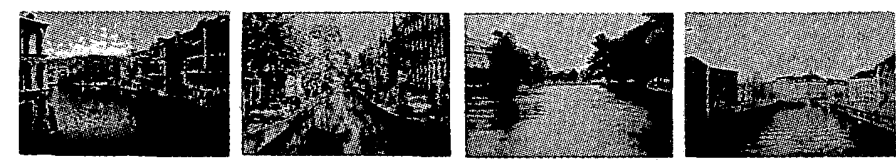

欧一1:ヘヘネチア(1)
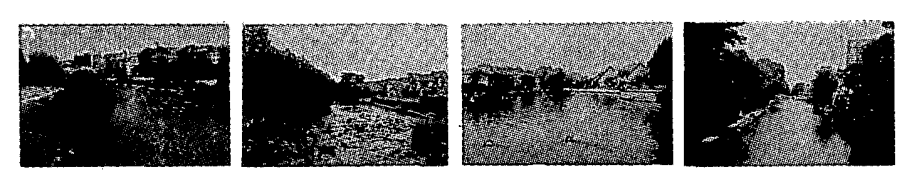

欧ー9:ウィーン(9)
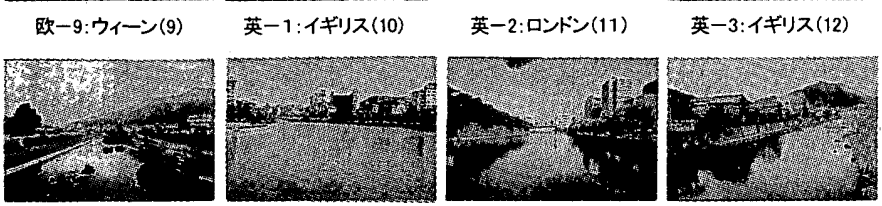

日一-3:広島 濑野川1 (17)

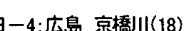

\section{3 呈示景観の内容}

実験で用いた河川景観は、筆者ら ${ }^{18)}$ が既に実施した国内外河川景 観に対する心理的評価実験で用いた国内、国外各 15 種の景観から、 特徵的な傾向の認められたものを選択するとともに、英国人、中国 人、日本人をそれぞれ被験者とすることから、特に英国と中国の河 川景観を適宜加えて決定したものである。景観の内容を写真-1に 示す。英国 5 種（№.10１4）、英国を除く欧州 9 種（№.1～9）、日 本 7 種 (No.15〜21)、中国 3 種 (No. 22〜24) であり、いずれも橋上 あるいはそれに類する流路中央付近から流路方向を撮影した流軸景 として、構図に統一性をもたせた。撮影には $28 \mathrm{~mm}$ の広角レンズ（水 平視野範囲約 60 度）を用いた注2)。なお、運河や水路、港湾など帯 状の人工的な水空間における景観も、正確には河川とはいえないが 幾つか選択している。

これら河川景観に対する心理的評価を説明する物理的特性として は、空や水面、建物など、景観を構成する種々の要素が、景観全体 に占める面積の比率（\%) を求めた。算出は、各景観写真をイメー ジスキャナで画像データとして取り込み、画像処理ソフトを用いて 同一内容の要素と判断される部分を同一色で塗り分け、最後に各色 のピクセル数を計数するという手順で行った。図ー1に、各景観ご とに区分した構成要素が占める面積の構成割合を示す。また、24 種 の景観全体について求めた各要素の面積比の平均值、標準偏差を表 -2 に示す。ここで、表中に示した構成要素のうち、『1 天空』〜『16 付設 $1 』$ は相互に独立の要素であり、『17 自然』〜30人工7』はそ れら独立要素の組み合わせによってそれぞれ定義した。なお、図-1 は独立要素による面積構成を示している。これより、24 枚の河川景 観においては、全面積のうち約 2 割が空で占められ、植栽や山など の緑と、住居やビルなどの建物がそれぞれ 1 割強、水面が約 4 割を 占めていることがわかる。

\begin{tabular}{|c|c|c|c|}
\hline \multicolumn{4}{|c|}{ 表-1 回答票の主な内容 } \\
\hline $\begin{array}{l}7 \\
x \\
1 \\
\pi \\
\vdots \\
1 \\
1\end{array}$ & 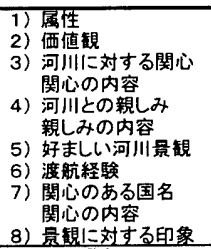 & 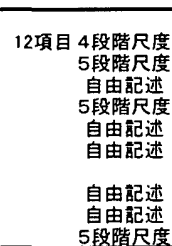 & 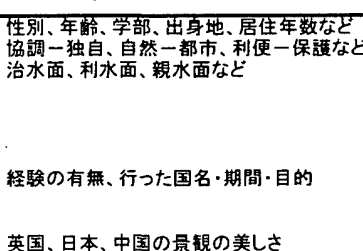 \\
\hline $\begin{array}{l}\text { 景钼 } \\
\text { 呯価 }\end{array}$ & 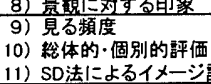 & 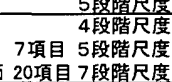 & $\begin{array}{l}\text { の別、両足意識、緑量など } \\
\text { かな、安らぞのある゙ }\end{array}$ \\
\hline
\end{tabular}

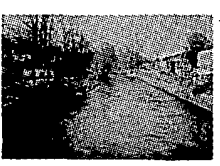

欧一5:イエープレ(5)

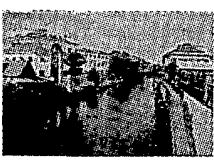

英一 $4:$ イギリス(13)

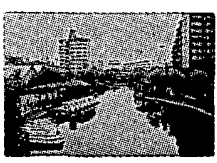

日-7:果京 横十間川(21)

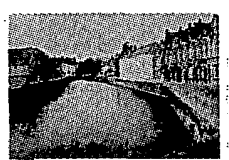

欧ー6:プルージュ(6)

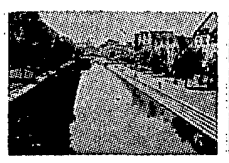

英一5:ロンドン(14)

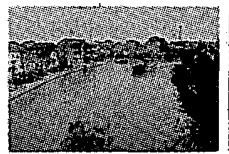

中-1:莯州(22)

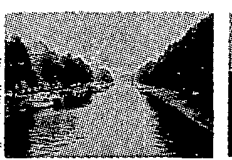

欧ー7:アムステルタム $(7)$

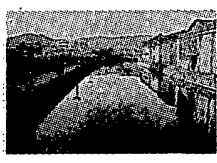

日ー1:小情 北海道(15)

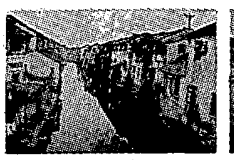

中-2:蒠州(23)

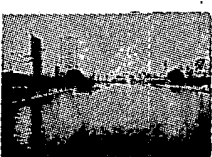

欧一8:パリ(8)

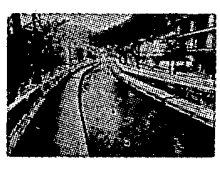

日-2: 兵庫 大蓉川(16)

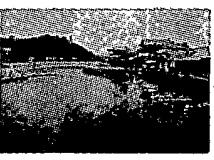

中-3:遥莱閣(24)

写真-1 呈示河川景観写真 


\section{4 被験者の属性}

被験者の属性は概略として (図表省略)、各国とも、6 7 割が男 性で、22 歳以下を中心に 20 代前半が主である。ただし、日本と中 国は全て建築学専攻の学生であるが、英国は建築学専攻の学生は半 数であり、多少の差異がある。河川に対する「関心てでは英国が最 も高く、「親しみでは 3 国とも全般に親しんできた被験者の方が多 い。また、国外への渡航経験については、英国では文化的共通性が 高い身近な西欧へはほぼ．100\%であるが、東アジアは皆無に近い。 日本では約 $40 \%$ 渡航経験を有し、その半数が東アジアである。中 国では渡航経験者はわずか $3 \%$ ある。

\section{3. 河川景観評価の心理的評価結果}

本章では、まず河川景観における総体的・個別的評価およびS D 法によるイメージ評価の心理的評価の結果について、英国・日本・ 中国間での相違について検討を行う。

\section{1 景観を見る頻度}

呈示スライドに類する景観を見る頻度（以後、「見る頻度」）に対 する回答は、評価者の属する生活環境や文化圏において日常的に接 触する景観と類似する場合に高頻度となることが予想される。4 段

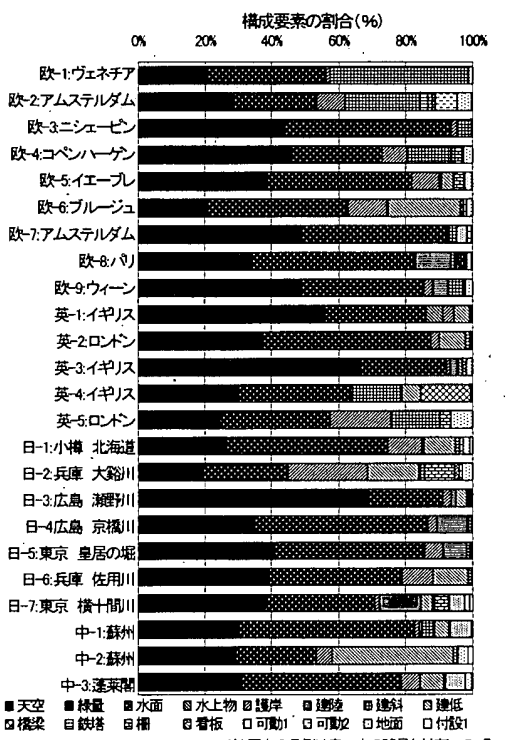

\begin{tabular}{|c|c|c|c|}
\hline 略号 & 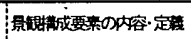 & $\begin{array}{l}\text { 平均 } \\
\text { (\%) }\end{array}$ & 摽萑 \\
\hline 崆 & 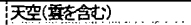 & 21.52 & 7.8 \\
\hline & E. 地木-山灰 & 08 & \\
\hline 面 & 面(形覞を含 & 7. 92 & 9.9 \\
\hline (1) & 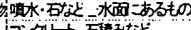 & 0.21 & 1.02 \\
\hline 諈岸 & 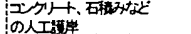 & 5.68 & 5.8 \\
\hline 铸 & 陸瓷根中部習建 & 206 & 3.79 \\
\hline & 候梌握 & & 8 \\
\hline & 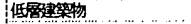 & 59 & \\
\hline 䨐 & & 0.74 & 3.04 \\
\hline & 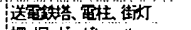 & 42 & 0.54 \\
\hline & 柵增· & 1.29 & 1.99 \\
\hline 存板 & 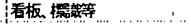 & 0.19 & 0.34 \\
\hline & & 0.86 & 1.94 \\
\hline 4 可野 & $i \sigma$ & 0.56 & 1.33 \\
\hline 泇面 & 也道路 & 1.52 & .55 \\
\hline & 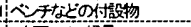 & 0.21 & 0.36 \\
\hline & 3水面 +2 緑量 & 54.00 & \\
\hline & 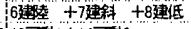 & 128. & 9.79 \\
\hline & 13 可蚛 +1 & 1. 42 & 2.25 \\
\hline & 216付設 + & 0.81 & 1.01 \\
\hline & & $2:$ & 2.5 \\
\hline & 421 付設 & 32 & 2.63 \\
\hline & 522 付設 $4+1$ & 73 & 3.62 \\
\hline & 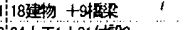 & 13.55 & 10.73 \\
\hline & & 6 & 11.32 \\
\hline & & $10^{\circ}$ & 11.90 \\
\hline & & 10 & \\
\hline & & 33 & \\
\hline & & & \\
\hline & & & \\
\hline
\end{tabular}

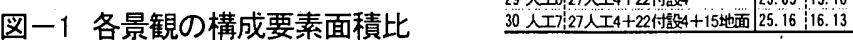

階尺度の回答に1〜 4の得点を付与し求めた平均評価得点ブロフィー ルを図ー2 に示す。なお、図中には景観ごとの平均評価得点に基づ いて算出した異なる 2 国間の相関係数を付した。

これより、英国、日本、中国の景観に対しては、それぞれ英国、 日本、中国で他の 2 国に比して頻度が高くなっており、いずれも自 国の景観に対しては高頻度となることがわかる。欧州の景観に対し ては、前述したように、同じ欧州圈に属する英国では、接触の機会 が豊富であることが予想され、日本や中国と比べて頻度が高くなっ ている。ただし、日本や中国では欧州のいずれの景観も同程度に頻 度が低いのに対して、英国では、欧 -1 、欧 -2 や欧 -8 、欧 -9 の頻 度が低くなっている。

また、中国の平均評価得点は、欧州や英国の景観では日本とほぼ 同程度で差異がないのに対して、日本の景観では日本と英国のほぼ 中間の值を示す。これより、日本と中国の差異は、気候や地理的条 件、文化的背景の共通性によって、西洋と東アジアとの差異ほど大 きくないといえる。このことは、中国の景観に対する日本の評価得 点が、英国と中国の中間であることからも裏付けれられる。

\section{2 総体的. 個別的評価結果}

総体的・個別的評価についても「見る頻度」と同様に、5段階尺 度に 1 〜の得点を付与し平均評価得点プロフィールを求めるととも に、景観ごとの平均評価得点に基づいて異なる 2 国間の相関係数を 算出した。主な 6 項目に関する結果を図一 3 に示す。

「国内外の別」では「見る頻度」之類似した評価傾向を示し、各 国とも共通して自国の景観を国内、それ以外の景観を国外と評価し ており、判断基準が極めて明確であることがかかる。自国の景観と 少なからず共通する部分があるため、欧州の景観に対する英国の評 価と、日本の景観に対する中国の評価は概ね中庸となる。しかし、 欧一1 や欧-2 のように、実際の接触経験の有無にかかわらず、ある 程度の知識があれば場所の特定が可能な特徽的な景観については、 英国の場合も国外之評価されており、中ー2 に対する日本の評価に ついても同様の傾向がうかがえる。一方で、欧－8 や欧－9 のように 近代建築が主な視対象となる景観や、英一3 のような植栽や樹木が 多くを占める景観については、特徵か䁔昧であるため中庸な評価に なっている。

「満足意識」では、 3 国ともほとんどの景観が中庸からやや満足

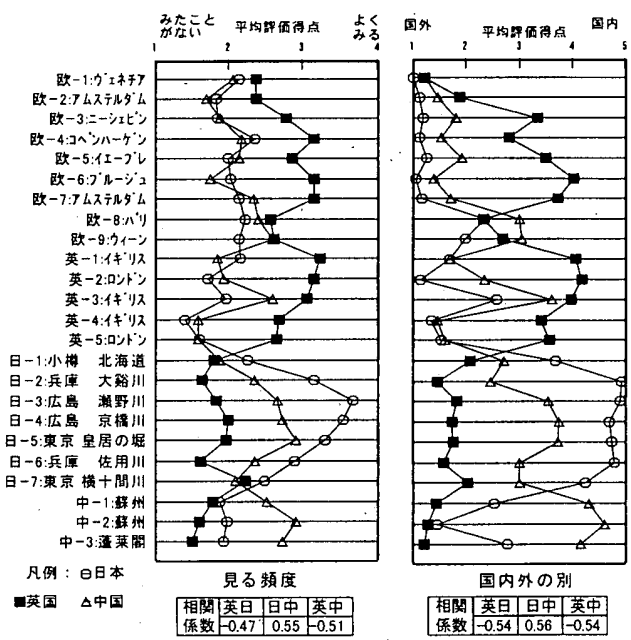

図ー2 景観を見る頻度の結果

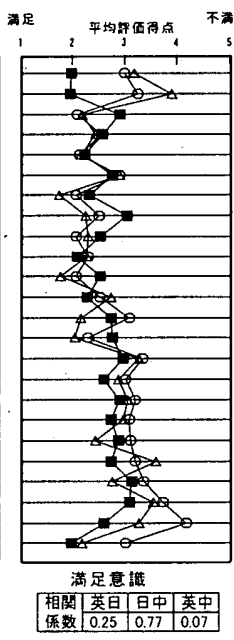

\begin{tabular}{|l|l|l|l|}
\hline 相閔英是 & 日中 & 英中 \\
\hline
\end{tabular}
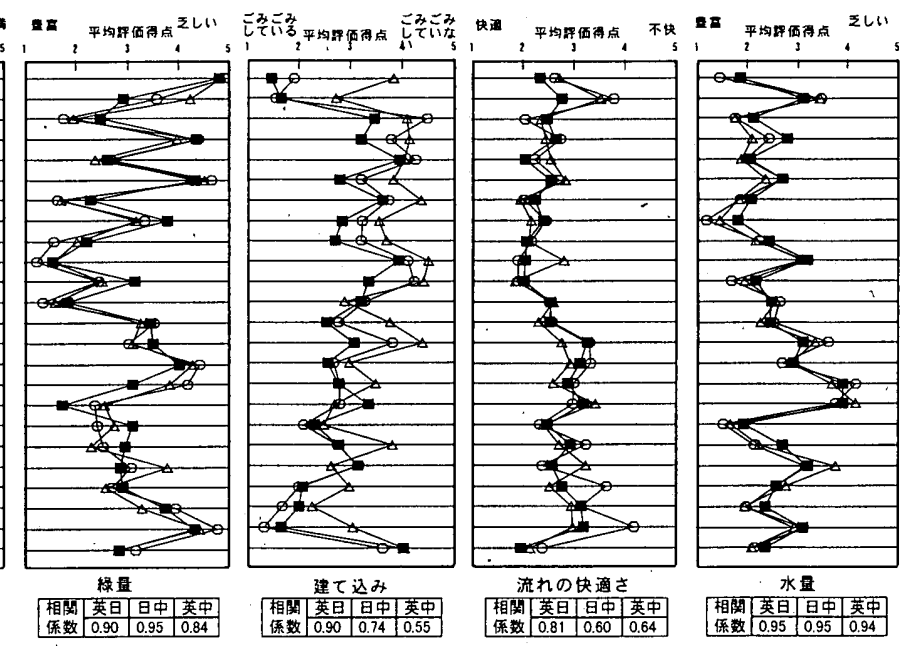

図-3 総体的·個別的評価の平均評価得点 
側に評価されているが、景観に占める建物の割合が大きいほど低評 価となる傾向がみられ、人工物の多少によって評価が左右されるこ とが示唆される。しかし、欧一1 や欧一2は建築物が多い景観である にもかかわらず、英国では満足側、日本と中国では中庸からやや不 満側に評価されており、差異がみられる。これは、前述したように 英国の場合には、この 2 景観が存在する地域を明確に認識している ことが予想され、景観そのものより地域全体の印象がより強く想起 されたため、高評価になったものと考えられる。

「緑量」では、いずれの 2 国間の相関係数も 0.8 を超え、3 国と もほぼ共通した評価傾向を示し、特に日本と中国では評価得点の差 異が小さい。樹木や芝生などが景観中に占める量によって評価が左 右される傾向を示し、構成要素に対する認識や、評価項目の意味内 容のとらえ方に 3 国間で極端な差はないものと考えられる。

「建て込み」では、欧一1、欧一2、中ー2 のような建物が連続し て並ぶ景観や、建物以外に自動車や人間などの要素を多く含む景観 について低評価となる傾向が共通してみられるが、形状や色彩の統 一性、緑量の多少も評価に影響していると考えられる。中国は、ほ とんどの景観について日本および英国と差異がみられ、より高い評 価になっており、欧一 1 や欧一2ではその差が顕著に現れている。英 国や日本では建物の量的な側面が評価に現れる傾向が強いが、中国 では建物の量や、自動車や人間などの要素が多くても、統一感のあ る景観に対しては必ずしも低評価になっておらず、「建て込み」の評 価項目のとらえ方において、建物の形状や存在形態がより考慮され ているものと考えられる。

「流れの快適さ」では、欧州および英国の景観に対して 3 国に類 似した評価傾向がみられる。また、日本の景観に対しても、英国と 日本、中国と英国の間で評価得点の差が少なくなつている。水面が 大きく広がった景観や水量が豊富な景観が概ね快適側の評価となつ ており、水面の様相や周辺環境とのバランスなど景観全体が考慮さ れているものと推測される。

「水量」では、3 国ともほぼ共通した評価傾向を示し、水面の大 きさによって評価が左右される.と考えられる。「緑量」と同様に評価 項目のとらえ方や判断の基準に大きな差異がないことが予想される。

図中に付した相関係数に基づいて以上の結果を整理するなら、「緑 量」や「水量」など、景観の物理的な特徵を直接的に示す項目では 3 国ともいずれも高相関を呈するが、「満足意識」では日本と中国の 相関は比較的高いものの、英国の評価傾向はこれら 2 国と比べ異な っており、欧一1、欧一2 や中国の景観に対する評価の差異による影 響が考えられる。

\section{3 イメージ評価構造の比較}

SD法によるイメージ評価 20 形容詞対については、はじめに、各 項目間の相互関連を把握し、英国、日本、中国の各国間での評価構 造の異同を検討するため、主因子法・バリマックス回転による因子 分析を各国ごとに適用した。固有值 1.0 以上の基準で抽出した 5 因 子の結果を表一 3 左欄に示す。ここでは、各形容詞対について、最 も高い因子負荷量を示した因子の抽出順をローマ数字で示した。以 下、日本の抽出順に従って、意味内容が共通すると思われる因子を 3 国間で相互に比較して検討を進める。

日本人の第 I 因子は、「好きな一嫌いな」「さわやかなーうっとう しい」などの因子負荷量が高く、景観の総体的な評価を示す『快適
性』と解釈される。この因子は英国、中国ともに第 I 因子として抽. 出されているが、因子負荷量の高い形容詞対を日本と比較するなら、 英国では「自然的な一人工的な」の負荷量が低く、「調和した一不調 和な」の負荷量が高くなっており、日本では自然的な景観が好まし く評価されるのに対して、英国ではやや全体的な調和が重視される ことがわかる。このことは、欧一1や欧一2に対する英国の高評価か らも裏付けられる。一方、中国では「整然とした一雑然とした」「統 一的なーばらばらな」など多くの形容詞対で因子負荷量が高く、景 観の統一性や整然性などの評価と総体的評価との関連が示陵され、 多様な意味性を有する寄与率の高い因子として抽出されている。

第II因子は、「英国的な一日本的な」「平凡な一特徽のある」など から『異国性』と解积できるが、英国、中国ではこれと意味内容の 共通する因子は抽出されていない。日本では、統一的で平凡な叔し い印象の景観を英国的、その逆を日本的と評価する傾向があり、「英 国的な一日本的な」を、言葉通りの意味ではなく、和と洋あるいは 西欧と東アジアの相違を示す、より広義な意味内容でとらえている ことが予想される。これに対して、中国では、「英国的な一日本的な」 における「日本的」という言葉を「中国的」と対比してとらえるこ とが予想され、選定した形容詞対のいずれとも関連性が低く、因子 として抽出されなかったものと考えられる。一方、英国では、「英国 的な一日本的な」は「親しみやすい一親しみにくい」とともに第IV 因子で因子負荷量が高くなっている。これは、日本や中国では総体 的評価と類似した意味内容でとらえられる「親しみやすい」という 言葉が、英国では「見慣れている」という意味でとらえられたため、

「英国的な一日本的な」の形容詞対との相関が高まったものと予想 される。

第而因子「統一的なーばらばらな」「整然とした一雑然とした」 などによる『統一性』、第IV因子「伝統的な一革新的な」などによる 『伝統性』、第V因子「活発な一おとなしい」「速い一遅い」などに よる『躍動性』は、それぞれ中国、英国でも抽出されているが、英 国では日本、中国と異なり、『統一性』ではなく、『伝統性』に整然 性や自然性の意味あいが含まれている。また、英国、中国では日本 と異なり、『躍動性』に「華やかな一寂しい」「複雑なー単調な」な どが含まれ、寄与率が高くなっている。なお、中国の第V因子、「大 きいー小さい」開放的な一圧迫感のある」に関する『開放性』は、 日本と英国では抽出されておらず、中国の場合、景観の開放感につ いてより関心が持たれているものと推測される。

\section{4 イメージ評価傾向の比較}

以上のように、各国とも抽出順は異なるが、いずれも『快適性』 『躍動性』『伝統性』『統一性』なる意味内容の共通した因子が得ら れており、社会・文化的背景の相違にもかかわらず、評価構造は概 ね安定していることがわかる。このことから、3 国間でイメージ評 価傾向の相違を把握するため、因子の意味内容を共通させ、因子得 点の值によって各景観に対する評価を比較することを考え、3 国の 統合デー夕に対して同様な手法による因子分析を適用した。ただし、

「親しみやすい一親しみにくい」については、上述したように英国 と日本、中国とで意味解釈が異なる可能性があるため、ここでは除 いている。また、各国の分析結果でいずれも 5 因子が抽出されたた め、抽出因子数として 5 因子を指定した。因子負荷量行列および各 因子の意味内容の解釈を表-3 の右欄に示す。中国の結果と共通す 

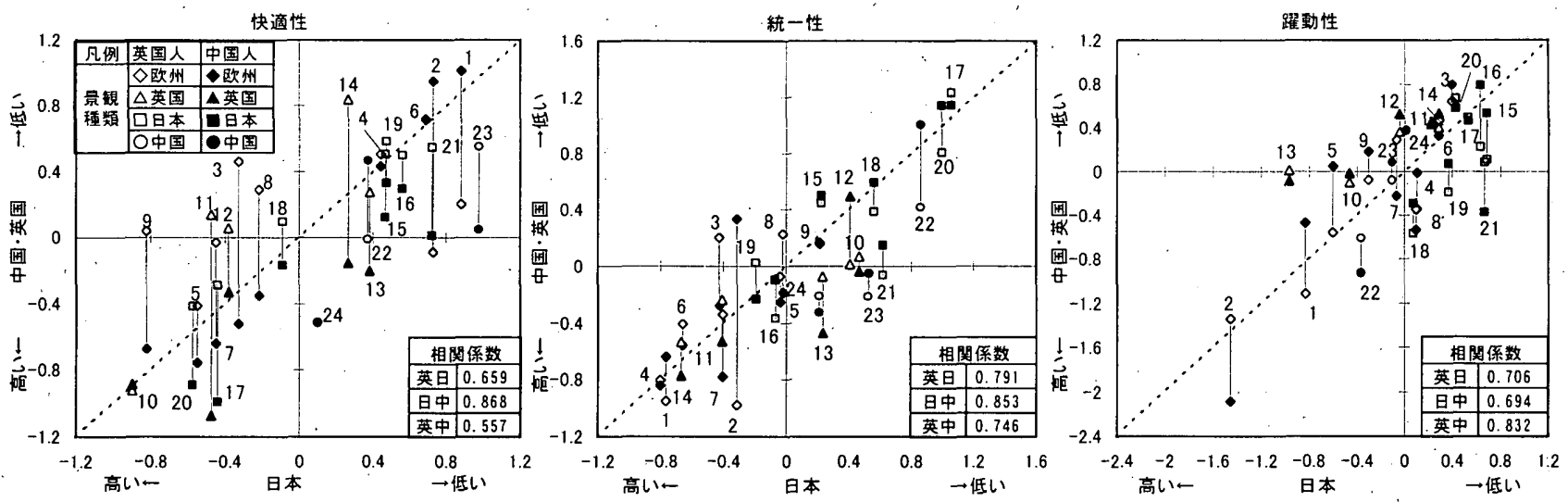

表ー3 イメージ評価の因子分析結果

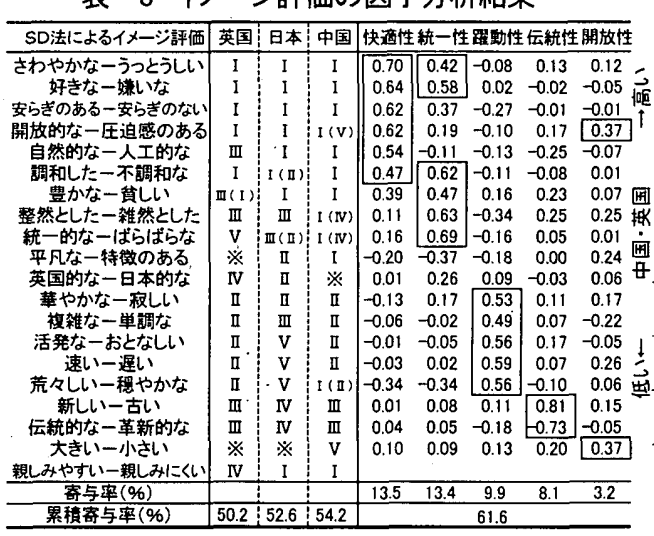

需与率 $(\%)$
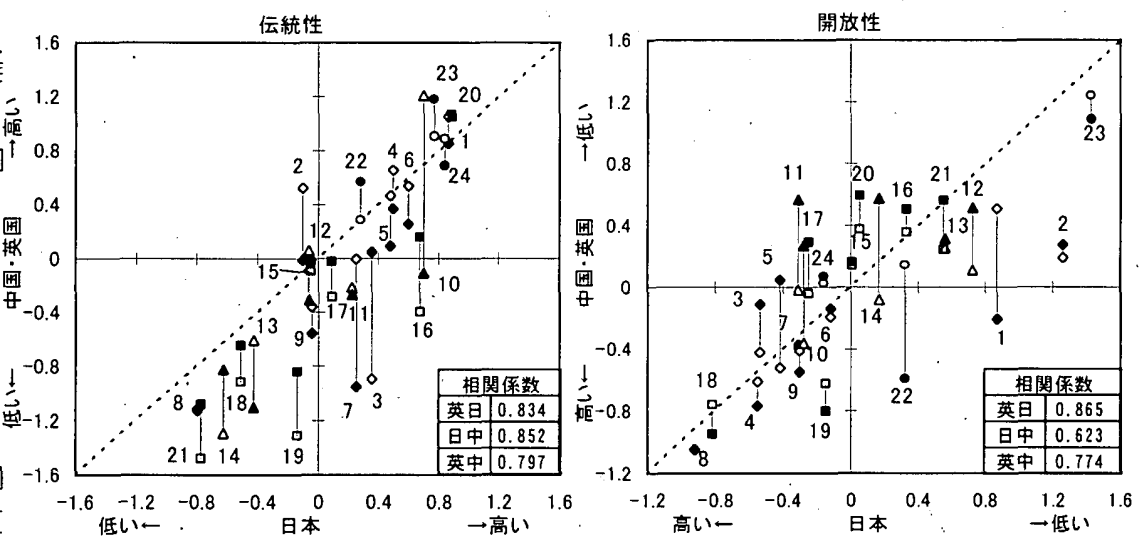

図ー4 平均因子得点による河川景観の布置

る『快適性』『統一性』『躍動性』『伝統性』『開放性』の5因子が抽 出されている。

この 5 因子について、各景観の平均因子得点を国別に算出し、評 価傾向を 3 国間で比較する。図一 4 に第 I 〜V因子それぞれについ て、横軸を日本、縦軸を英国並びに中国の值として各景観を布置し た結果を示す。また：図中には 24 種の景観をサンプルとして求めた 異なる 2 国間の相関係数を付した。

『快適性』では、日本と中国の評価傾向加類似しており、英国は 異なることがわかる。特に欧州の景観において差異がみられ、「満足 意識」でも述べた欧－1(No.1)、欧一2(No.2)の評価が英国で高くな る傾向がここでもみられるほか、欧一-3(№.3)や欧-8(№. 8))、欧一 9(№.9)では日本や中国に比べ英国の評価が低く、緑量が多く自然的 な景観にこのような傾向が認められる。これより、自然が豊富で人 工物が少ないほど景観の総体的評価が向上することは、日本や中国 では共通して得られるが、英国では多少異なる判断基準のもとに評 価が行われていることが示唆される。また、日本と中国の違いとし て、中国では、中国の景観に対する評価が高く、自国の伝統的な景 観を肯定的にとらえていることや、カラフルで新しい整備の日ー7 (No. 21) や英一5(No.14) などの評価が高いことなどが挙げられる。

『統一性』では、3 国間でほほ評価傾向か類似する。このことは 異なる 2 国間の相関係数の結果からも確認でき、建物の意匠や材料 などに統一性のある欧州や英国の景観で高評価となり、日本や中国 の景観で低評価となる傾向が英国、日本、中国のいずれでもみられ ることから、判断基準がある程度共通するものと推測される。 間で差異のみられる景観としては欧ー2 (№.2)が挙げられ、日本の評 価を基準とするなら、種々雑多な事物の混在した景観であることか
ら中国では低評価となるのに対し、全体的な印象、色彩調和性など から英国では高評価となっているものと考えられる。

『躍動性』では、3 国に共通して、多くの人々や自動車など可動 物があり、カラフルな色彩で華やかな印象を与える欧一2(№.2)、建 物が水際まで迫る欧－1 (No.1)、水面に小波が立ち、流れを感じさせ る英一1 (No.10)などの評価が高く、冬季や最天、夕暮れなどで色調 にそしい日ー1 (No.15)、日ー2(No.16)などの評価が低くなっており、 水面の動きや人々の活動など要素の動的性質のほか、景観全体の印 象も判断の基準になっていることがわかる。一方、英国と中国の相 関係数の值は高いが、英国、中国と日本の相関係数はやや低い值を 示しており、同一の文化圈に属する日本と中国では相関の高いこと が予想されたが、必ずしもそのようになっていない。

『伝統性』も『統一性』と同様に、日本と中国の相関係数が最も 高いが、英国と日本、中国の評価傾向もほぼ類似する。3 国に共通 して、欧一1 (No. 1) や日-6 (No. 20)、中-2(№.23)、中-3(No. 24) など、歴史のある建物や街並みが高評価の要因となり、地域固有の 特徵に乏しい近代建築が主となる景観や、周辺の開発や整備が近年 行われた景観で評価が低くなっている。これに対して、欧一3(No.3)、 欧一7(№.7)、英-1 (No. 10)、英-3(№.12)、日一5(№.19)などの景 観では 3 国間で差異がみられることから、緑量が豊富で、建物の少 ない景観においては、『伝統性』を判断する要素か曖昧となり、着目 する要素に対する考え方が 3 国間で異なることが予想される。

『開放性』では、英国と日本の相関係数が高く、中国と日本では 低い值を示す。全般には、欧－8(No.8)や日ー4(No. 18)などの評価が 高く、中一2(№.23)の評価が低いことから、水路の幅員並びに広が りと周辺建物の高さが3国に共通する判断の基準として考えられる。 
ただし、中国では欧ー1 (No. 1)や中ー1 (No. 22) の評価が高く、英国や 日本と傾向が多少異なっている。

\section{4. 河川景観の規定要因分析}

前章では、3国間での心理的評価の相違について検討を行ったが、 本章では、心理的評価のうち総体的・個別的評価の結果に基づき、 景観の物理的特性を示す指標としてとらえた景観構成要素の面積比 との関連について、英国、日本、中国それぞれを分析し、評価を判 断する基準として前述した定性的知見を検証するとともに、社会・ 文化的背景による相違を明確にする。

\section{1 景観の物理的特性と心理的評価の関連性}

はじめに、24 種類の河川景観をサンプルとして、総体的・個別的 評価の主な 6 項目の平均評価得点と、16 種類の独立要素およびそれ らの組み合わせによる14種類の合成要素の面積比との相関係数を算 出した。結果を表一 5 に示す。

「国内外の別」では、日本、中国ともに『7 建斜』『6 建陸』との 関連がみられ、傾斜屋根の建物が多いと国外、陸屋根の建物が多い と国内と判断されることがわかる。英国はこれら 2 国と異なり、『10

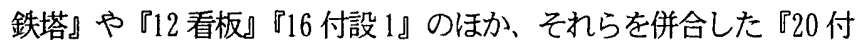
設 2』で相関係数の值が高く、建物自体よりむしろそれに付属する 雑多な要素の有無によって、判断か行われているものと考えられる。

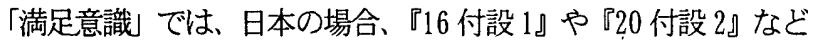
の要素が評価の低下に寄与するとともに、『17 自然』や『18 建物』 『25人工 2 などでも相関係数がある程度の值を示し、自然や人工 物の総量による影響も認められる。中国も日本とほぼ類似した傾向 を示すが、『14 可動 2』『12 看板』との高い相関係数から、日本より 雑多な要素による寄与の大きいことがわかる。一方、英国では、『6 建陸』や『7 建斜』との関連がみられ、伝統的景観が高く評価され ることがわかる。

「緑量」では、3国とも『2 緑量』や『17 自然『18 建物』との相 関係数が高い値を示し、景観の具体的内容を示す項目の場合、判断 基準の共通性の高いことが確認できる。ただし、英国では『2 緑量』 が最も高い值を示すのに対して、日本、中国では『2 緑量』に『3 水面』を加えた『17 自然』の值が最も高い。英国では項目の意味内 容に直接対応する物理的特性によって評価が決定されているのに対

表一5 心理的評価と構成要素面積比との関連

\begin{tabular}{|c|c|c|c|c|c|c|c|c|c|c|c|c|c|c|c|c|c|c|}
\hline \multirow{2}{*}{ 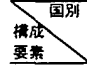 } & \multicolumn{3}{|c|}{ 国内外の別 } & \multicolumn{3}{|c|}{ 満足意满 } & \multicolumn{3}{|c|}{ 积基 } & \multicolumn{3}{|c|}{ 遇て识み } & \multicolumn{3}{|c|}{ 流れの快適さ } & \multicolumn{3}{|c|}{ 水量 } \\
\hline & 英国 & 日本 & 中国 & 英国 & 日本 & 中国 & 英国 & 日本 & 中国 & 英国 & 日本 & 中国 & 英国 & 日本 & 中国 & 英国 & 日本 & 中国 \\
\hline 조오 & - & - & - & - & - & - & - & - & - & 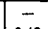 & - & - & - & - & - & - & -0.41 & -0.30 \\
\hline & 0.33 & $\begin{array}{l}- \\
-\end{array}$ & - & - & -0.37 & & -0.88 & 0.76 & 0.68 & 0.40 & - & - & - & - & - & 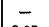 & & \\
\hline & & - & - & $=$ & _ & & & & & 03 & $\overline{-}$ & & 0.31 & & & -0.67 & & \\
\hline & 0.31 & $\bar{z}$ & - & $\bar{z}$ & - & $\bar{z}$ & -0.39 & -0.35 & -0.33 & 0.31 & - & 0.30 & - & $z$ & - & - & $-\overline{0}$ & \\
\hline & $=$ & $\overline{0.45}$ & 0.36 & 0.47 & - & $\overline{-}$ & $\overline{-}$ & $\underline{-0.38}$ & 0.41 & $\overline{-}$ & $=$ & 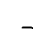 & 0.34 & $\bar{z}$ & - & 0.59 & $\begin{array}{r}0.65 \\
-0.35\end{array}$ & 0.52 \\
\hline & & -0.45 & -0.54 & -0.40 & - & - & 0.43 & 0.39 & 0.46 & -0.48 & - & - & - & - & - & - & - & - \\
\hline & - & - & - & - & 0.53 & - & 0.36 & 0.51 & 0.48 & - & - & - & - & 0.40 & & 0.37 & 0.36 & - \\
\hline & -038 & $=$ & $=$ & $\overline{-}$ & $\overline{0.4}$ & $-\overline{0 .}$ & - & - & $-\overline{054}$ & $-\overline{51}$ & $-\overline{52}$ & $-\overline{036}$ & $\overline{0}$ & $\overline{069}$ & - & $-\overline{0.38}$ & $\overline{0.42}$ & - \\
\hline & & - & & - & 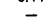 & & - & 0.40 & - & - & -0.02 & -0 & -0 & - & 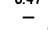 & & & 0.35 \\
\hline & -0.36 & - & & - & - & 0.37 & - & - & - & -0.31 & -0.35 & - & - & 0.34 & - & 0.50 & 0.52 & 0.42 \\
\hline & \pm & $\overline{-}$ & $\begin{array}{r}0.39 \\
-0.30\end{array}$ & 0.35 & 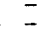 & 0.40 & $\overline{-}$ & - & $=$ & -0.31 & $\overline{-}$ & $\overline{-}$ & $=$ & $\overrightarrow{0.34}$ & $\overline{0.38}$ & - & - & - \\
\hline & $=$ & $\overline{-}$ & -0.30 & -0 & - & & - & 0.34 & 0.37 & - & - & - & 0.36 & 0.53 & -0 & 0.34 & 0.50 & 0.35 \\
\hline 16 扵敕 1 & 0.41 & $=$ & 0.44 & $\approx$ & 0.64 & 0.38 & & & 3 & 0.42 & -0.53 & -0.38 & 0.39 & 0.89 & _ & 1 & - & - \\
\hline & 0.34 & - & - & - & -0.51 & & -0.74 & -0.81 & -0.79 & 0.52 & 0.45 & - & -0.36 & & - & -0.30 & -0.31 & - \\
\hline & -0.37 & - & - & - & 0.51 & 0.43 & 0.72 & 0.74 & 0.78 & -0.76 & -0.62 & - & - & 0.52 & - & - & - & - \\
\hline & & $\begin{array}{ll}- & \text { - }\end{array}$ & - & - & - & - & - & - & - & - & -0.32 & - & - & - & - & - & - & - \\
\hline & -0.48 & - & - & - & 0.54 & 0.58 & - & 47 & 0.51 & -0.53 & -0.59 & -0.42 & 0.45 & 0.73 & 0.43 & 0.43 & 0.46 & 0.41 \\
\hline & - & - & - & 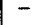 & - & - & - & 0.07 & - & - & - & - & - & 0.43 & - & & & 0.48 \\
\hline & - & - & - & - & - & - & - & - & - & - & - & - & - & 0.30 & - & 55 & 0.59 & 0.49 \\
\hline & - & - & - & - & - & - & - & - & - & - & - & - & - & 39 & - & 0.35 & 0.42 & 0.33 \\
\hline & & - & - & - & & & 59 & & דרק & & & - & - & 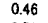 & - & - & - & - \\
\hline & 0.33 & - & - & - & & & & & & & & - & & 53 & - & - & - & - \\
\hline & -0.35 & - & - & - & & & & & & & & - & & $\delta /$ & 0.36 & 0.32 & 0.40 & 0.31 \\
\hline & & - & - & - & & & & & & & & - & & & 31 & & 0.38 & \\
\hline & -0.31 & - & - & - & & & & & & & & - & & & 31 & 35 & 43 & 33 \\
\hline${ }_{30}^{29}$ 人I 6 & .30 & $\bar{z}$ & $\overline{-}$ & $\overline{-}$ & $\begin{array}{l}0.41 \\
0.39\end{array}$ & $\begin{array}{l}0.36 \\
0.34\end{array}$ & $\begin{array}{l}0.57 \\
0.56\end{array}$ & $\begin{array}{l}0.72 \\
0.71\end{array}$ & $\begin{array}{l}0.74 \\
0.74\end{array}$ & $\begin{array}{l}-0.53 \\
-0.53\end{array}$ & $\begin{array}{l}-0.43 \\
-0.44\end{array}$ & $\bar{z}$ & $\begin{array}{l}0.36 \\
0.37\end{array}$ & $\begin{array}{l}0.56 \\
0.58\end{array}$ & $\begin{array}{l}0.31 \\
0.31\end{array}$ & $\begin{array}{l}0.42 \\
0.42\end{array}$ & $\begin{array}{l}0.51 \\
0.53\end{array}$ & $\begin{array}{l}0.38 \\
0.40\end{array}$ \\
\hline
\end{tabular}

し、ほかの 2 国では「緑量」を自然の豊富さに近い、より広義の概 念としてとらえている可能性が示唆される。

「建て込み」では、英国、日本ともに『18 建物』の相関係数が最 も高いが、日本より英国の値が高く、建物の総量を判断の基準とし て評価する傾向が、英国の場合により強いことがわかる。一方、中 国では、前述したように、建物が多くても全体に統一性があれば必 ずしも低評価にはならないことから、『18 建物』との関連は明確で なく、『20 付設 2』との関連がみられるにとどまっている。

「流れの快適さ」では、3 国ともにほぼ共通した要素が挙げられ る。日本の結果に着目すれば、「満足意識」と関連する『16 付設 1 』 や『20 付設 $2 』 に$ 加え、『3 水面』との関連がみられ、水体に関する 評価であると同時に総体的評価の性格も併せ持つ、項目の意味内容 をよく反映した結果であるといえる。また、英国では雑多な要素の 方が、中国では水量の方がそれぞれ評価との関連がより強いことが 特徵として挙げられるが、いずれも日本に比べ全般に相関係数の値 は低くなっている。

「水量」では、『3 水面』で相関係数の值が 3 国ともに高く、特に 日本で顕著な傾向を示す。「緑量」と同様に景観の具体的内容を示す 項目であり、判断基準の共通性が高いことがわかる。

\section{2 河川景観の規定要因分析}

次に、筆者らが導出した、景観構成要素の面積比を用いて心理的 評価を求める予測式を適用し、物理的特性と心理的評価との関連性 についてさらに検討を進める。

既報 ${ }^{15)}$ では、コンピュータ画像処理で作成した全く架空の河川景 観を用いた実験結果に基づき、総体的・個別的評価をそれぞれ従属 変数とし、7 種の景観構成要素の面積比を説明変数として重回帰分 析を行い、予測式を求めた。本研究では、その予測式に基づいて、 総体的·個別的評価各項目の予測値 (以下、予測值と呼ぶ) を求め、 実際に今回の実験によって求められた評価結果（以下、実測値と呼 ぶ）との比較から、3 国間での国内外河川景観に対する評価構造の 異同を検討する。

まず、既報 ${ }^{55)}$ の重回帰式に説明変数として投入した 7 種類の構成 要素との統一を図るため、表一6に示すように改めて統計量を整理 した。ここで扱つた 7 要素のうち、『建物』は、表一2 中の『18 建物』 と『21 付設 3 とを、『護岸』は、『5 護岸』と『9 橋梁』とを加算し たものである。『緑量』『水面』『天空』は、『2 緑量』『3 水面』『1 天 空』の統計量をそのまま用いている。また、『人工』は、『建物』·之 『護岸』の加算、『自然』は『緑量』と“水面』の加算によりそれぞ れ求めた。そして、これらの構成要素に基づいて、既報の予測式 (図 -5の各項目の夕イトル横に示している)による予測値を算出した。 主な 5 項目について、図一5に横軸を予測値、縦軸を実測値とした 国別の各景観の布置を示す。また、これら項目の予測值と実測值と の相関係数を表 -7 に示す。

「満足意識」では、日本では、日本や中国の東アジアの景観と、 英国や欧州の西洋の景観との 2 群に分かれて布置され、それぞれで 実測值と予測值との間に直線的な関係がみられ、相関のあることが わかる。東アジアの景観に比べ、西洋の景観が全般的に高く評価さ れ、景観における東洋と西洋の質的な相違を前提に、それぞれを異 なる対象群としてとらえ、満足意識が評価されたものと予測され、 既報 ${ }^{15)}$ 之同様な傾向が確認できる。英国では、欧-1 (No. 1)、欧一 

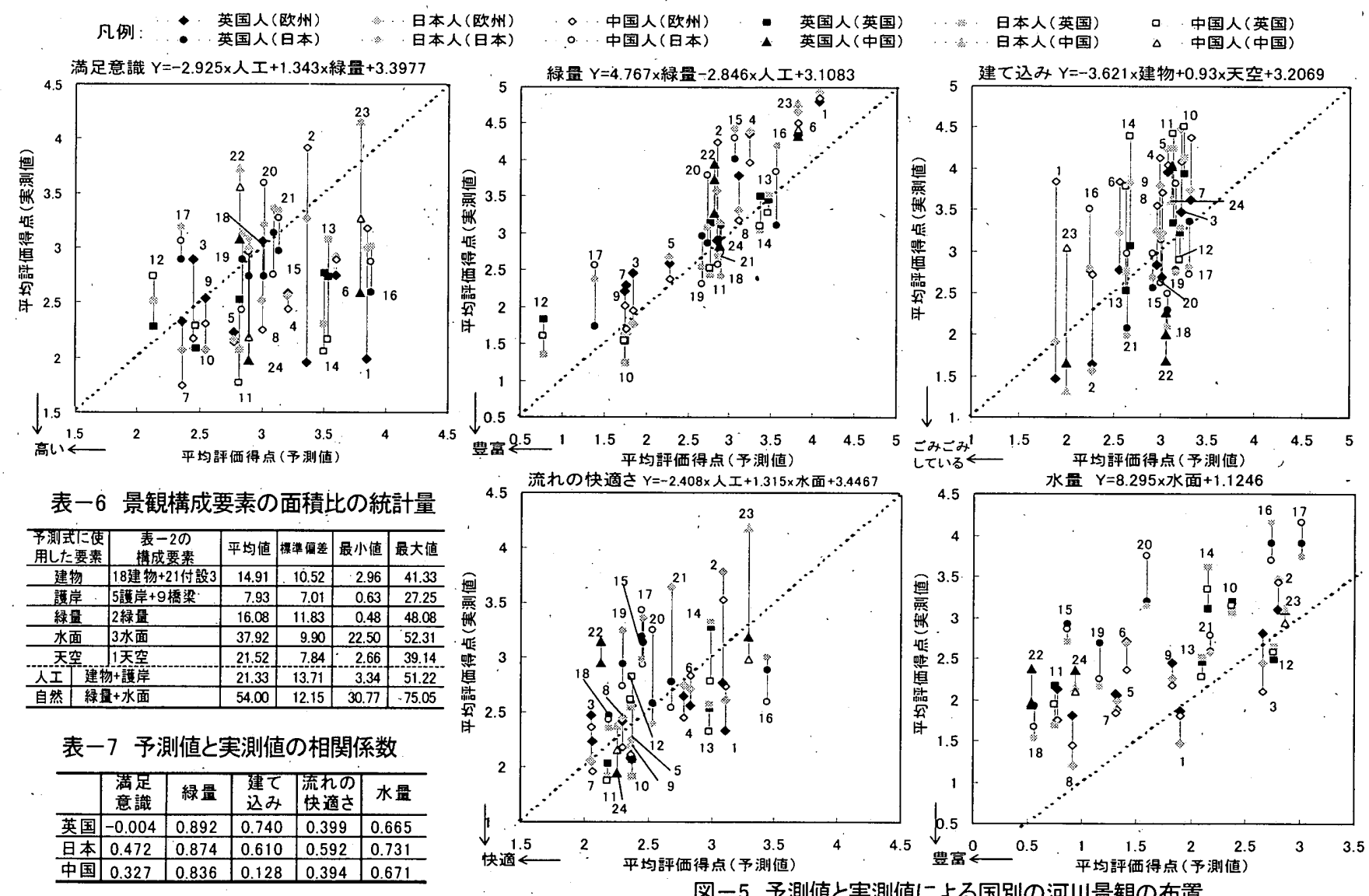

表-7 予測値と実測値の相関係数

\begin{tabular}{c|c|c|c|c|c}
\hline & $\begin{array}{c}\text { 满足 } \\
\text { 意識 }\end{array}$ & 緑㽬 & $\begin{array}{c}\text { 建て } \\
\text { 迄み }\end{array}$ & $\begin{array}{c}\text { 流れの } \\
\text { 快適さ }\end{array}$ & 水量 \\
\hline 英国 & -0.004 & 0.892 & 0.740 & 0.399 & 0.665 \\
\hline 旦本 & 0.472 & 0.874 & 0.610 & 0.592 & 0.731 \\
\hline 中国 & 0.327 & 0.836 & 0.128 & 0.394 & 0.671 \\
\hline
\end{tabular}

2 (No: 2) で予測値より実測值が高いほか、日ー2(№. 16)，中一 2 (№. 23)、欧一6 (No. 6) などの景観においても同様な傾向を示してい る。これらの景観には地域の伝統的なイメージが共通して現れてお り、東広島市の留学生を対象とした既報 ${ }^{22)}$ の結果でもみられたよう に、英国ではそれぞれの噮境における伝統性を重視する傾向がみら れ、それが「満足意識」を左右する要因となることが推測される。 中国では、欧-2 (№. 2)、英-3(№. 12)、日一6(№. 20)、中-1 (№. 22) など、両岸に乱雑に建物や植生が並ぶ景観や、船、付設物などの目 立つ景観で㬰測值が低く、その逆に、英-5(№. 14)、日-2(№. 16) など、両岸に建物や植生が整然と並んでいる景観について実測值が 高くなっており、景観における建物や植生の統一性が「満足意識」 に影響していることが示唆される。

「緑量」「水量」では、低評価側から高評価側までの景観の順序は 3 国ともに共通しており、構成要素の面積比に代表される量的側面 の影響が大きいことがわかる。ただし、「緑量」では、欧ー1 (№.1)、 中-2 (№. 23)など緑が全くない景観において、実測值より予測值が 高くなっている。これは、予測值が『人工』構成要素も含めて算 出されているためである。また冰量 では、『水面』が大きな面積 を占める影観が多いのに対し、実際の評価では水路の広さだけでは なく、深さも併せて考えられていることから、実測値より予測值が かなり高い值を示す。

「建て込み」では、英国の場合、「緑量」と同様に予測值と実測値 がほぼ等しい。中国については、欧-1 (№.1)、中ー2 (№. 23)などの 景観で、実測值のほうが「ごみごみしていない」と評価され、建物 か密集しているにかかわらず、ある程度整列していれば、肯定的に 評価されることが把握でき、前述と同様な傾向か認められる。日本

の場合は、中-2(№. 23)，欧一2 (№. 2)、日ー7(№. 21)など、建物の 様式が多様な景観、あるいは、両岸が人や船、自動車などで混雑し ている景観で、予測值より実測值が「ごみごみしている」と評価さ れ、逆に、欧-3(No. 3)、英-2 (No. 11)、中-3(№. 24)などの建物が 統一している景観では「ごみごみしていない」と評価されており、 単純に建物や空の面積ではなく、建物と周辺との調和性も「建て込 ぬ」の評価に関保があることが示唆される。

「流れの快適さ」では、日本の場合は、「満足意識」之同様に、中 国之日本の景観において、概ね予測值より実測值が低くなっている 一方、欧州之英国の景観においては高くなっており、総合的評価と 考えられる「満足意識」之同様な傾向がうかがえる。しかし、水量 が少なく、日本の景観でもある日ー2(№.16) では、実測值の方が高 くなっており、整備された護岸および両岸に並ぶ伝統的な旅館と水 の流れのイメージとが統合され、よい影響を与えていると考えられ る。英国と中国では、予測値之実測值の間にあまり高い相関はみら れず、『人工』や『水面』などの構成要素の量的側面のみではなく、 「満足意識了で述べたような伝統性や統一性による影響も考えられ、 出身国の文化的特性や個人の㪘好などが反映される評価項目である と考えられる。

国別にみる相関係数の值から実測値と予測值の関連を概括するな ら、3 国に共通して最も高い相関係数を示す項目として「緑量、次 いで「水量】が挙げられ、総体的䛨価の「満足意識」では相関係数 が低く、特に英国で著しい。また、「建て込み」では、英国と日本で は相関係数がやや高く、中国では比較的低い値を示す。

以上の結果から、評価傾向に基づいて定性的に予測された、心理 的評価それぞれに影響を及ぼす要因について、実際の物理的特性と 
の関連を検討することによって、改めて確認することができた。さ らに、「緑量」や「水量」など、認知の初期段階で客観的情報として 取得される景観の物理的特性に関する心理的評価の場合、直接的に 対応する要素が存在すること、また、「満足意識」における、中国、 日本と異なる英国の評価傾向などから、個人の嗜好や価値観、景観 から受け取る意味性の違いが大きく反映する総合的評価においては、 判断の基準が個人特性によって相違する可能性があることなどがよ り明確に把握された。なお、予測式の適用性という観点からみるな ら、「満足意識の結果から地域を超えた普遍的な適用には問題か残 ること、国によってとらえ方の異なる統一性や伝統性などの側面を 反映させた予測式の改良が今後の課題となることなどが示唆される。

\section{5. 結語}

本研究では、回答者の個人特性が環境評価に及ぼす影響を考える 際、国という生育環境の違いが社会・文化的背景の相違として重要 な要因であると考え、異なる出身国の被験者として、英国、日本、 中国それぞれの大学生を取り上げ、河川景観における心理的評価の 比較分析を行った。また、景観の物理的特性との関連性から出身国 間での異同を検討し、社会・文化的背景の相違が景観の認識・評価 構造に及ぼす影響を把握した。得られた知見をまとめて以下に示す。 1）はじめに、河川景観における総体的・個別的評価の平均評価得 点から、「緑量」や「水量」など景観の物理的特性に関する個別的 評価で、英国、日本、中国の 3 国間の評価傾向の共通性が高いこ と、これに対して、「满足意識」や「流れの快適さ」などの総合的 評価においては、3 国間で差異の大きいことを把握した。

2) SD法による 20 形容詞対のイメージ評価構造では、因子分析を 国ごとに適用した結果から、3 国に共通して『快適性』『躍動性』 『伝統性』『統一性』の 4 因子が抽出された。さらに、3 国の統合 テー夕による因子分析を行い、各景観の平均因子得点を国別に算 出した結果から、『快適性』など総合的評価で 3 国間で差異がみら れた。総体的・個別的評価でもみられたように、自然の豊富さや 人工物の多少によって評価がある程度左右されるものの、日本、 中国に比べ、英国では判断の基準がやや異なること、被験者と異 なる文化圈や地域に属する、接触経験の少ないことが予想される 景観をより魅力的に感じる傾向があることを示した。

3）次に、心理的評価のうち、総体的・個別的評価における主な 5 項目の平均評価得点と、景観の各構成要素の面積比との相関係数 を求めた。「緑量」や「水量」などの個別的評価については、直接 対応する要素が存在するのに対し、「満足意識」など総合的評価で はそれほど明確な関連がみられないことがさらに検証できた。

4）最後に、心理的評価と物理的特性との関連をより明確に比較す るため、既報の河川景観の心理的評価の予測式に基づいて、総体 的・個別評価の予測値を算出し、実際の平均評価得点と比較した。 これによって、景観の物理的特性と直接対応する個別的評価項目 では、3 国間の共通性が高く、個人の啫好や景観から受け取る意 味性の違いが大きく反映する総合的評価においては、判断基準が 3 国間で異なることが判明した。

\section{【謝辞】}

中国版および英伍版の回答票の作成にご協力いたたいた金沢大学講師沈振江先生 （当時、広島大学助手）をはじめとする方々、実験の実施にあたりご劦力いただい
た大連理工大学崔鴻林先生・ロンドン大学の諸先生方、最後に実験に協力していた だいた学生諸君に謝意を表する。なお、本研究の一部は平成 10 年度文部省科学研 究費補助金 C(2)（代表 : 西名大作）によったことを記す。

【注】

1）総体的砰価は、景観の満足度や、全体の景色の良さなど、景観中の要素を個々 にとらえるのではなく、総体的に考慮した上で回答する項目を指す。個別的評価 は、緑量や水量、建てこみなど、景観中の貝体的な構成要素についての質問項目 を指す。これらの各評価項目は参考文献 15) で用いた項目と同一であるため、総 称としても既報と同様に「総体的・個別的評価 なる記述に統一した。

2）河川影観は、対岸方向、左岸あるいは右岸方向、流軸方的などさまざまの視点から撮

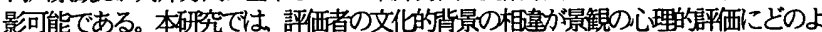
うに影響を及ぼすかを明らかたすることを暗図している。したがって、河岸や、河岸 にある建物や付設物などか泣体的に表見され，河小疄境を構成する要素力遍く一望で きることから、景観の有する種々の文化的特牲力汉映される流䌷景を採用している。 視点の変化によって景観の様柤力変わり、要素の面棈割合も大きく変化するが 既住 研究において、構汹がる程度統一している景観群においては，個々の要素力評価に 及ぼす影每さ 相效的には類以した䝨向を示すという結果を得ている。

【参考文献

1）讃井純一郎，乾 正雄 : 個人差及ひ階層性を考慮した住環境評価構造のモデル 化 認知評価心理学に基づく住環境粨価に関する研究 (2)，日本建築学会計画 系論文報告集，第 374 号，pp.54-60，1987年 4 月

2) 槙 究 中村芳㑬, 乾 正雄 : 街路景観評価の個人差について, 日本建筑学会計 画系論文集、第 483 号, pp.55-62，1996年 5 月

3）鈴木誠，田崎和裕，進士五十八：外国人の日本庭溒観に関する比較研究。造園雑 誌、VOL52, NO5, pp.25-30,1989年 3 月

4) 杉尾扼江 : ニュージーランド人と日本人の住宅庭園景観に対する意識に関する比

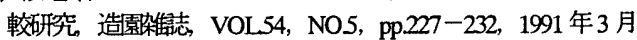

5）岡島達堆、金 東永、麓 和善, 内藤 昌:日本・韓国伝統建筑空間ハイメージ 評定尺度抽出一日本·韓国伝統建築空間のイメー溡性 (その1), 日本建筑学会 計画係論文集，第 458 号，pp.171-177，1994年 4 月

6）岡島達雄，金 東永，麓 和善, 内藤 昌: 構成部位・要素加みた日本・韓国 伝統建築のイメー溡性一日本・韓国伝統建空間のイメー溡性 (その2)，日 本建学会語画系論文集，第 464 号, pp. 209-214，1994年 10 月

7) 金 東久 岡島墶夫, 麓和善, 黄 武達 内藤 昌:日本·台驾伝統建空空間の イメー溡性、日本建築学会計画係論文集 第 475 号, pp. 203-208, 1995年9月

8) Buhyoff, G. J, Wellman, J. D., Koch, N. E, Gautier L. \& Hultman, S.: LandscapePreference Metrica: An Intemational Comparison, Joumal of Environmental Managerment, VOL16, pp.181-190, 1983 年

9) Tips, W.E J. \& Sabasdisara, T.: The influence of the environmental background ofsubjects on their landscape preference evaluation, Landscape and Uiban Planning VOL.13, pp. 125133,1986 年

10) Nasar, J. L: A cross-cultural comparison between Japan and United States, Joumal of Cross-Cultural Psychology, VOL 15, pp. 79-93, 1984 年

11) Yu, C.: Cultural variations in landscape preference: Comparison among Chinese sub-groups and Westem design experts, Landscape and Uiban Planning VOL 32, pp. 107-126, 1995 年

12）西名大作，村川三郎，金 華: 東広島市における留学生の生活境境伻価に関する研 究 日本建築学会計画系論文集，第 529 号，pp.101-108，2000年3月

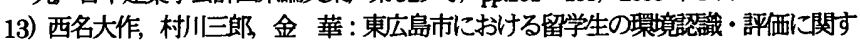
る研究その1 調查概要と個人特性に関する検討, 日本建学会大会学術諎演梗 概集D-1, pp.811-812, 1998年

14）西名大作，村川二郎，金 華: 東広島市における留学生の環境伺識・評価に関す

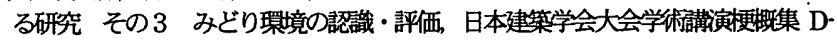
$1, \mathrm{pp} .781-782,1999$ 年

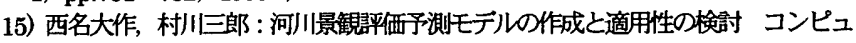
一夕画像処理による河川票境評価に関する研究 その2, 日本建学学会計画系論文 集、第494号, pp.61-69,1997年4月西名大作，村川三郎，飯尾招彦 金 華

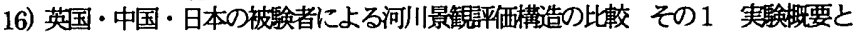

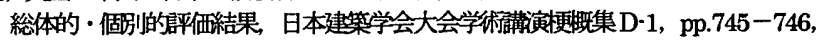
2000 年

17）金 華 村川三郎、飯尾昭彦，西名大作: 英国・中国・日本の被験者による河川 景観钎価構造の比較 その2 イメーシ評価結果と物理的特性との関連性。日本建 築学会大会学術满演梗甠集D-1, pp.747-748,2000年

18）西名大作，村川三郎：国内外河川景観の評価特性の比較分析，日本建策学会計画 系論文集，第 491 号，pp. 57-65，1997年1月

(2000年 9 月 6 日原稿受理, 2001 年 1 月 16 日採用決定 